\title{
On Security Mechanism in China and US: Comparison and Practices
}

\author{
Gangzhi Zhou, Li Feng \\ Law School, Central South University, Changsha, P. R. China \\ Email address: \\ 1921187435@qq.com (Gangzhi Zhou)
}

To cite this article:

Gangzhi Zhou, Li Feng. On Security Mechanism in China and US: Comparison and Practices. International Journal of Law and Society. Vol. 3, No. 4, 2020, pp. 154-160. doi: 10.11648/j.ijls.20200304.11

Received: July 8, 2019; Accepted: August 12, 2019; Published: October 17, 2020

\begin{abstract}
It is understood to all national states that national security system serves as an essential role in security mechanism. Both United State and China have confronted security challenges from home and abroad. As for the US, since the founding of the country and especially after US has engaged in global affairs, with the shift of national security concept and security realities, the security constitutional system has undergone several major adjustments. The National Security Act, which was passed by congress in 1947, has created a new organ named National Security Council to integrate the Defense and Intelligence Agencies and build a new security constitution system. After the 9/11 incident, the US congress passed the PATRIOT Act, which has greatly expanded the security powers of the President. With regards to China, China has a long history of safeguarding its territorial integrity, so it is obvious that China focuses more on traditional threats since 1949. After its reform and opening-up policy, the international environment has become more complex and the protection of non-traditional security has become more prominent. Since China has entered a new era in $21^{\text {st }}$ century, various laws and regulations targeting the traditional and non-traditional threat has been enacted. From a historic perspective and comparative approach, this paper finds that China is learning the practices and legislation experiences from countries like United states to actively build a legal system for national security and form a more efficient and integrated security mechanism. in addition, a security constitutional system with the core concept of "overall national security concept" is beginning to take shape. China is building a comprehensive security system to address both traditional and non-traditional national threats.
\end{abstract}

Keywords: Security Mechanism, Overall National Security Concept, Culture Security, Security System

\section{Introduction}

The national security system is an important part of the entire national system. It is a set of complete organizational structure, corresponding system and operation process formed or established by sovereign states to maintain their relative stability, integrity and freedom from threats, fears and encroachment. [1] The core part of the security system is "security constitution", which includes the concept and principles of national security in the constitution, security power system and coordination mechanism, etc. Historically, the security systems of all countries in the world have undergone a major transition from emphasizing "national military security" to focusing on "overall national security". Because of globalization, "cultural security" and other "non-traditional security" issues have become increasingly prominent, and the reconstruction of security constitutional system has become an urgent issue facing all countries. Therefore, we can refer to the changing process of the security constitution of the United States, and describe the basic process and plans of China's reform of the security constitution system.

\section{The Changes and Enlightenment of American Security Constitution System}

\subsection{The Security Constitutional System After the Founding of the United States}

America's security system grew out of the militia system set up in the early days of the colonies to compete with Indians for land and other resources. The north American militia emerged from the British and French colonial wars of 1756 to 1763. 
After the British victory, they decided to garrison their troops in North America and asked the north American colonies to bear part of the military expenditure, which inspired the north American revolutionary war. Influenced by liberal ideology and other factors, the United States quickly disarmed after the victory of the revolutionary war. In 1784, the standing army was first reduced to 700, then to 80. [2] But events such as the Daniel Shays uprising have forced Americans to rethink their security systems. In 1787 , the federal constitution of the United States finally stipulated that congress has the power to tax, declare war, recruit and maintain the navy and army (the army has only two years of funding), and the President of the United States is "commander in chief of the army, navy and militia of the states commissioned to serve in the United States". To prevent a Cromwellian crisis, the framers of the US constitution deliberately created a militia system "run by the state in peacetime and commanded by the President in wartime", to curb the growth of the standing army. However, because of the Independence War, US-Mexico war and other wars, the standing army of the United States is still in a state of constant adjustment. The US Supreme Court in 1950 denied the similarities between presidential and monarchical powers by declaring that the President had "pure military (command) authority" rather than just "commanding the army and navy". However, during the civil war and world war Two, presidents used the commander-in-chief clause to expand the President's powers, such as appointing military personnel, issuing administrative instructions and orders, and using civilian ministers as tools to lead the armed forces. [3] Historically, the traditional security system of the United States mainly aims to maintain national defense security, and tries to maintain the traditional state militia system and the congress-led system based on the "combination of peacetime and wartime" militia system and the foreign policy of "isolationism" as the principle. However, after the United States participated in the second world war, not only its foreign policy underwent a major adjustment, but also its national security system faced a major adjustment.

During World War Two, after the United States turned to war as a neutral country with a small foreign policy agencies, its national security organization also expanded sharply. The expansion of the United States military and the subsequent equipment institutions that fought in the two war zones resulted in the confusion of the internal decision-making process of the military. The US military is divided in structure and lacks effective cooperation. After Pearl Harbor, the Senate set up a special committee to examine defense programs. Truman, as chairman of the committee, recognized the waste and inefficiency of resources caused by the division and in coordination between the army and navy. Integration at home and after the war department opinions of the admiralty, Truman in 1945 on December 19, put forward the union address to congress, proposed that "the establishment of a unified defense, solely responsible for armed to protect the security of the country", "one each defense minister assistant, and divided the land, sea and air forces", "'chief of staff and the army, navy and air force commander of the three should constitute as the secretary and the President's advisory body". [4] The US congress enacted the National Security Act of 1947, which stipulated that the national security council was chaired by the President, and when the President was unable to personally attend the chairmanship, a member was appointed to act as the chairmanship. The standing members of the National Security Council are: 1. President 2. Secretary of state; 3. Minister of defense; 4. Minister of army; 5. Minister of the navy; Minister of the air force; Chairman of the national security resources committee (History of national Security Council). The National Security Act of 1947 also created several new institutions, including the creation of the national security council, the Central Intelligence Agency, and the National Security Resources Council, the establishment of an independent air force department, and the establishment of the Department of Defense. Retained the joint chiefs of staff during the war; and created a new set of military departments, and so on. [5] Since then, the President has reformed the security council to make it more adaptable to the new security situation. For example, President Eisenhower combined federal agency reform with the national security council to create a broader inter-agency system. These include the creation of a US Information Agency independent of the State Department to promote public diplomacy; Establish a consultative committee on foreign intelligence activities to provide the President with an independent analysis of U.S. foreign intelligence programs; The establishment of Civil Political Advisers in the military as civilian staff officers for military commanders (Projection on National Security Reform). After the reform of President Nixon and President Reagan, the National Security Council of the United States not only guarantees the security of the United States, but also realizes the coordination between the security agencies and other national agencies. In addition, During the 1970s, non-state actors called for the foundation of a private democracy promotion organization to overcome strategic and organizational dilemmas which had resulted in the US state limiting its export of democracy in favour of short-term national security objectives and restraining state-private network organizations during the Cold War. [6]

\subsection{The Security Constitutional System of the United States After 9/11}

As mentioned above, after World War Two, especially during the cold war, the United States gradually constructed the "National Security State" system under the concept of "overall Security concept", extended the original "National defense Security" to "National Security", and realized another transition of the Security constitutional system after the founding of the United States. [7] On Sept. 11, 2001, in the worst terrorist attack on the United States, the twin towers of the world trade center in New York and the Pentagon were hit and destroyed by hijacked civilian planes, killing about 3,000 people. After the investigation, the 9/11 Commission concluded that the national security intelligence system of the United States was deficient in structure and function, and could not prevent and defeat terrorist attacks well. Thus, 
reforming the U.S. intelligence system has become an important goal of President Bush. The U.S. Congress passed the Intelligence Reform Act on December 17, 2004, which makes the biggest reform of the U.S. intelligence system since World War Two. The 9/11 attacks made the United States realize that international terrorism is a major threat to the United States. Faced with "non-traditional threats," the Bush administration has made major changes in its national security philosophy.

After 9/11, the U.S. government also enacted several laws to improve its security system to accommodate "non-traditional threats" such as terrorism. For example, on September 22, 2001, President Bush signed The Airport and Transportation Security Act, establishing The Air Transportation Stabilization Board by implementing stricter airport passenger screening, adding plainclothes police officers to flights to strengthen civil aviation Security. The Oct. 25, 2001, USA PATRIOT Act Of 2001 allowed law enforcement agencies to tap the phones of suspected terrorists and track their Internet and email use, and allowed the Justice Department to detain suspected aliens for seven days before filing criminal charges and deportation. The Enhanced Border and Security and Visa Entry Reform Act of 2002, which requires the submission of information on aliens entering the country to the department of homeland Security; In June, the homeland security information sharing Act of 2002 promoted information sharing among intelligence and law enforcement agencies. On July 16, 2002, the Bush Administration released the first "national strategy for homeland security" report in the history of the United States, which made an overall and strategic plan for the domestic security policy of the United States. In November 2002, President Bush signed the National Security Act of 2002 into law, creating the Department of National Security. The United States has passed several bills to integrate its intelligence communities and ensure that the U.S. government has accurate information about terrorists who might endanger U.S. security. During Obama Administration, "In performing their respective jobs, the military and state and local civilian officials of the USA rarely interact but increasingly they are relying upon each other" [8].

\subsection{Enlightenment from the Change of American Security Constitutional System}

In addition to the legislative controversy, the "war on terror" of the United States not only breaks through the "right to self-defense" rule in international law, but also causes the substantial transfer of the right of the congress to declare war. [9] This shows that the change of American security constitutional system still faces many legal dilemmas. But the changing constitutional structure of the United States is needed to adapt to its changing security situation. In the context of the transition from "traditional security threat" to "non-traditional security threat", the United States believes that the source of the threat to its national security has changed from the foreign military threat to the terrorist activities of individuals or groups. To strengthen intelligence collection and processing, the security system of the United States needs to balance the powers of various Departments, and finally forms the central decision-making institution under the direct leadership and chairing of the head of state, including think tanks and information and intelligence processing mechanism, but with the central institution as the core, the decision-making system can be connected from top to bottom. The security system of the United States centers on the President. The National Scurity Council, the National Economic Council, the Homeland Security council, the Office of the Director of Intelligence and other mechanisms or institutions are set up to assist the President in his coordination and decision-making. Functional departments such as the Department of Defense, the State Department, the Central Intelligence Agency, and the Department of Homeland security are responsible for implementation. The US has sought greater coordination between its military, foreign policy and development wings of government. This has heightened in the post-9/11 period. [10]The safety regime has shown early signs of working. In the historical period when China is faced with "non-traditional threats", the security system of the United States has the important function of rapidly collecting intelligence, integrating department strength and maintaining national security, which merits China's reference.

\section{The Changes and Composition of China's Security Constitutional System}

\subsection{China's Security Constitutional System During the Planned Economy Period}

Article 42 of the 1954 Constitution clearly stipulates: "the President of the People's Republic of China directs the armed forces throughout the country and serves as chairman of the national defense commission." When the constitution was drafted in 1954, MAO Zedong's unified leadership of the military as chairman of the People's Republic of China and chairman of the central military commission of the communist party of China was in line with the expectations of MAO and other leaders of the central committee of the Communist Party of China, because he was the only one in charge at that time. "In 1959, the first session of the second National People's Congress elected Liu Shaoqi as the second President of the People's Republic of China. Since then, MAO has ceased to be President, but he did not resign as chairman of the Party's military commission. The fact is that MAO is always in command of the national armed forces. That creates difficulties for Liu Shaoqi as President". [11] The separation of the posts of "chairman of the state" from "chairman of the central committee of the Communist Party of China" in China's state power system ended with the death of chairman Liu Shaoqi. In March 1970, MAO proposed the convening of the fourth National People's Congress and the revision of the constitution, demanding that the state system be changed and no President be appointed. This recommendation was finally reflected in the 1975 Constitution. Article 15 of the Constitution clearly states: "The tasks of the armed forces of 
the People's Republic of China is to defend the achievements of the socialist revolution and socialist construction, safeguard the sovereignty, territorial integrity and security of the state, and defend against subversion and aggression by imperialism." Article 19 of the 1978 Constitution clearly stipulates: "the armed forces of the People's Republic of China are under the leadership of the chairman of the central committee of the communist party of China. The PLA is an army of workers and peasants led by the Communist Party of China and a pillar of the dictatorship of the proletariat. The fundamental tasks of the armed forces of the People's Republic of China are: to defend the socialist revolution and socialist construction, to defend the sovereignty, territorial integrity and security of the state, and to defend against subversion and aggression by social imperialism, imperialism and its lackeys. "The Constitution of 1975 and the Constitution of 1978 have slightly different descriptions, but both have the chairman of the central committee of the communist party of China as the "commander in chief" of the country's armed forces.

\subsection{China's Security Constitutional System During the "Reform and Opening up Period"}

In 1982, the CPC central committee no longer established the position of Party Chairman, and the general secretary presided over the work of the secretariat of the CPC central committee. Since then, the two posts of general secretary of the CPC central committee and chairman of the CPC central military commission are no longer held by one person. The constitution of the People's Republic of China in 1982 restored the title of "President of the state", but not the title of "commander-in-chief of the armed forces" in the 1954 constitution. Chapter Three and the fourth term of the constitution set up the posts of "central military commission of the People's Republic of China" and "chairman of the central military commission". Based on the CPC central military commission's political and military tradition of leading the people's liberation army, article 93 of the constitution merely adds the title of "central military commission of the People's Republic of China" to the former CMC. Only after the change of the central military commission of the communist party of China during the period of about half a year before the meeting of the National People's Congress, China will appear at the same time there are "of the central military commission of the Chinese communist party" and "of the central military commission of the People's Republic of China" two team's combination, gradually formed a general secretary of the CPC central committee and the central military commission chairman and President by a person holding national security decision-making power system. However, after the reform and opening up, China is faced with more and more complex international situation, pressing pressure on the protection of "non-traditional security", and many challenges to the national security system.

\subsection{China's Contemporary Security Constitutional Reform}

In the Research Report on China's National Security (2014), some scholars regard "the issue of violent terrorism", "cyber security" and "environmental security" as "non-traditional security threats". [12] So what is China's "traditional security problem"? Before the end of the cold war, national security mainly refers to military security". [13] From the perspective of legislative provisions, the "military security concept" embodied in article 2 of the defense law of the People's Republic of China in 1997 can be described as a "model" of China's "traditional security concept". That is, "to guard against and resist aggression, to stop armed subversion, and to defend the sovereignty, unity, territorial integrity and security of the state", etc. And the National Security Law of the People's Republic of China article 2, article 3 and article 8, embodies the new security concept, this is known as "overall national security concept", known as: "the state power, sovereignty, unity and territorial integrity, the people's welfare, economic and social sustainable development and other major national interest is relatively safe and is not affected by the internal and external threat" (article 2), it includes "internal and external security, homeland security and national security, traditional security and non-traditional security, its security and common security". The changes and development of China's security legislation indicate that China's national security concept is undergoing a transformation from the "traditional (political power) security concept" (the national security concept that takes the survival crisis of the regime as the object) to the "modern (national) security concept" (the national security concept that takes the survival crisis of the state as the object). The establishment of the national security council marks the profound transformation of China's security constitutional system.

\section{Reconstruction of China's Security Situation and Security Constitution}

\subsection{Changes in China's Security Situation in Recent Years}

Some scholars believe that there are many motivations for the reform of national security decision-making mechanism, but "the change of international pattern", "the development of globalization era", "the drive of information technology revolution" and "the direct birth of unexpected events" are the fundamental and universal motivations. [14] In recent years, the positive progress of China's anti-terrorism legislation reflects the profound changes in China's national security system promoted by various factors. On October 29, 2011, the standing committee of the National People's Congress in the resolution of issues related to counter-terrorism work points out: "terrorism refers to making social panic, endangering public security or stress state organs, the international organization for the purpose, to violence, destruction, intimidation, or intention caused casualties and major property damage, damage of public facilities and social order of serious social harm behavior, and incite, funding, or in other ways to assist the implementation of the above activities. Terrorist organization refers to a criminal group formed to carry out terrorist activities. Terrorists refer to those who organize, plan 
and carry out terrorist activities and members of terrorist organizations." On the basis of the resolution, in China's criminal judicial practice, only by state organs, the international organization for the purpose of "stress" of "organized crime would be considered" terrorism crime, and other individual activities, although some scholars also referred to as "individual terrorist crime", but Chinese officials are generally the qualitative as "personal extreme violent crime", and "violent terrorist crime" in parallel $[15,16]$. In fact, "individual extreme violent crimes" and "violent terrorist crimes" mainly threaten political and social security; In the current era of rapid development of globalization, the increase of exchanges between countries and between nationals and foreigners also makes the "non-traditional security" of countries such as "economic security" and "cultural security" in a dangerous state.

Some scholars believe that cultural security is the fundamental value orientation system of national grand strategy. The significance of cultural security to national security is to analyze, judge and position the current situation and future development goals of the country". [17] In fact, in a broad sense, "culture" is the way a nation lives. Therefore, "cultural security" is closer to "national security", and its core system is the core value system of "state-nation". Since modern times, the great achievement of modern science and technology research, under the support of the European and American countries borrow the name of the discipline of cultural anthropology and opportunely, attempting to create and to the establishment of the international law regulating the global order.

\subsection{The Reconstruction of China's Security Constitution}

When we want to analyze presidential systems, the US Constitutional convention had three schemes, namely "absolute presidential system", "presidential system of congress" and "presidential system of separation of powers". Finally, the us chose "presidential system of separation of powers". [18] The key to the presidential system of the United States is precisely that the country can only have a President as the executive head, who can centralize the leadership to exercise executive power and thus generate strong administrative efficiency. If there are multiple presidents exercising different executive powers, it is not presidential system but similar to cabinet system or other systems. China's current espionage law, formerly known as the national security law, indicates that the Chinese government has been focusing on "traditional security areas" such as "aggression or subversion by foreign forces". This "national security concept" is far from meeting the need to maintain China's national security after the end of the "cold war", so it is replaced by the "overall national security concept" in the new "national security law". In the long run, China's new concept of "overall national security system" will inevitably require the gradual establishment of a security system in which all Chinese departments coordinate and act in concert.

On November 12, 2013, China formally established the Central National Security Commission. This kind of system reform thought, effectively draws lessons from the American security committee system, is the party central committee reconstructs the Chinese national security leadership system the embodiment. At present, although "the National Security Council" is still the central coordination, decision-making body of the Communist Party of China, but its purpose is to maintain China's "national security", its specific functions were reflected in article 4, article 5: "stick to the communist party of China on national security work of leadership, establish a centralized and unified leadership, efficient and authoritative national security system." "The central national security leading body is responsible for the decision-making, discussion and coordination of national security work, studies, formulates and guides the implementation of national security strategies and relevant major policies and policies, coordinates major national security issues and important work, and promotes the construction of national security rule of law." Since then, the CPC central national security committee and its chairman are in the process of forming a "great security system" to coordinate the NPC and its standing committee, the state council, the central military commission and local people's governments, people's courts and people's public security organs and security organs.

\subsection{China's Measures to Restructure the Security Constitutional System}

China has made great effort to restructure security system recently. China has enacted several laws during the past ten years to integrate its security mechanism and counter non-tradtional threat. For instance, Articles 7 and 8 of the Anti-Terrorism Law of the People's Republic of China clearly stipulate that "the state shall establish a leading body for counter-terrorism work to uniformly lead and direct the counter-terrorism work throughout the country." "Public security organs, state security organs, people's courts, judicial and administrative organs and other relevant state organs shall, in accordance with their division of power, implement a system of job responsibility and do a good job in the fight against terrorism in accordance with law. The Chinese People's Liberation Army, the Chinese People's Armed Police Force and militia organizations prevent and deal with terrorist activities in accordance with this law and other relevant laws, administrative regulations and military regulations, as well as the orders of the State Council and the Central Military Commission, and in accordance with the arrangements of the leading organs for counter-terrorism work. Relevant Departments should establish linkage and coordination mechanisms to rely on and mobilize villagers' committees, neighborhood committees, enterprises, institutions and social organizations to jointly carry out counter-terrorism work." Therefore, China's anti-terrorism power system led by the ministry of public security is also in the process of establishing.

But the Anti-Terrorism law "established by the Ministry of Public Security as the national counter-terrorism leading institutions, the anti-terrorism mechanism is widely involved in public security organs, the Chinese People's Liberation 
Army, the Chinese People's Armed Police Forces, State Security Organs and People's Courts and Judicial Administrative organs and other relevant state organs (article 5 and article 11). According to the law of the People's Republic of China Armed Police Law article 3, the provisions of article 7, China's Amed Police is responsible for "to participate in the treatment of the riot, riots, violent crime, terrorist attacks and other social safety incidents" and other functions, but they "led by the state council and the central military commission, the combination of unified leadership and decentralized command system". Obviously, this is a leadership system different from the ordinary police in the public security department. In particular, article 43 of theAnti-Terrorism Law of the People's Republic of China stipulates that: "the national counter-terrorism intelligence center shall be established by the national counter-terrorism leading agency to implement the inter-departmental and inter-regional intelligence information working mechanism and coordinate the counter-terrorism intelligence and information work. Relevant departments shall strengthen the collection of counter-terrorism intelligence information, and submit timely and unified information on relevant clues, personnel and operations to the accordance with relevant provisions. Local counter-terrorism work leading institutions shall establish inter-departmental working mechanism of intelligence information, and organize anti-terrorism intelligence information work, the important information, it shall timely report to the superior anti-terrorism work leading institutions, involving in other parts of the emergency information, it shall timely report the relevant areas." Therefore, as a department of the state council of China, the ministry of public security, together with other departments and under the leadership of the central national security commission, needs to establish an "inter-agency intelligence information operation mechanism". In the field of "non-traditional (military) security" such as cultural security and economic security, China also needs to establish an efficient security decision-making mechanism through "inter-departmental intelligence information operation mechanism".

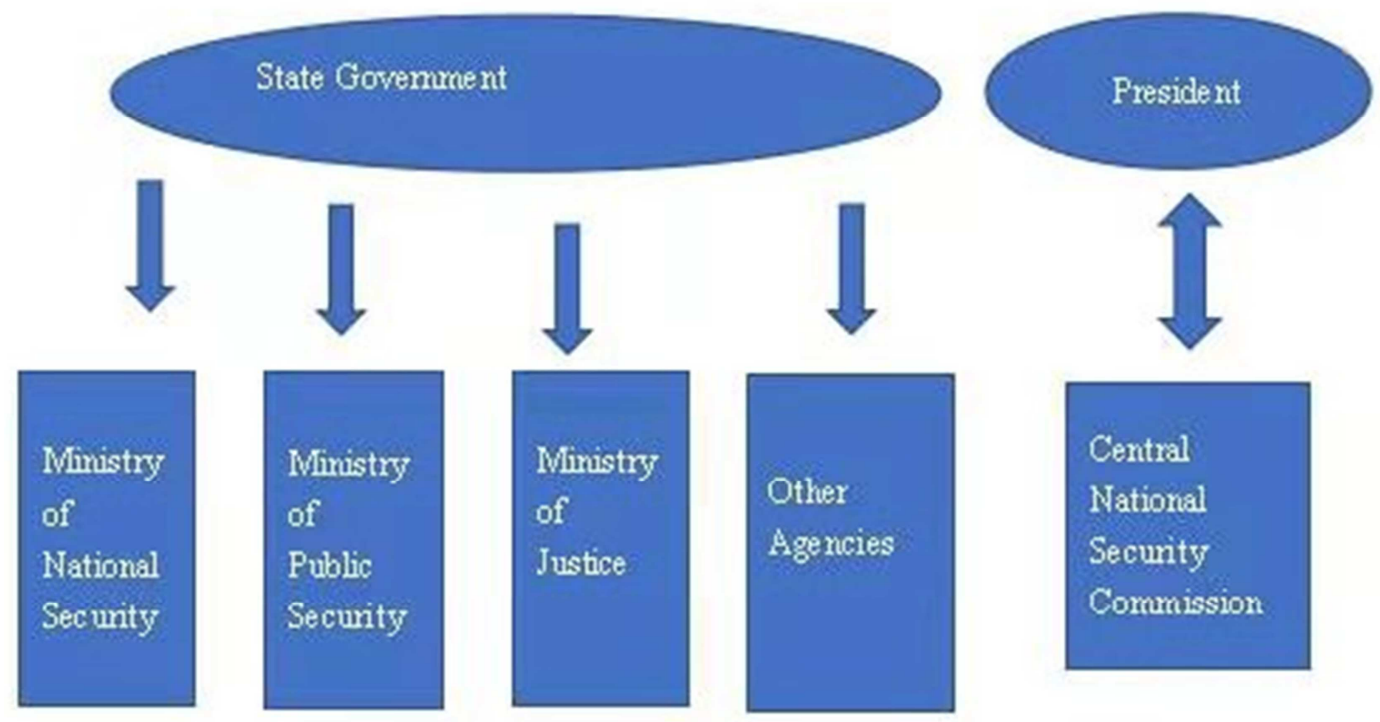

Figure 1. The relevant agencies of China's national security system.

\section{Conclusions}

The change of security constitutional system is the system change that all countries make to realize the concept of national. China's national security system was first established in the early days of the People's Republic of China. After the reform and opening, China is facing an increasingly complex international situation, and "cultural security" and other "non-traditional security" issues are increasingly prominent. Since the year of 2013 when the new leadership has come into power. China has set up the central national security committees and enacted new anti-espionage law, national security law and other laws, reflecting the new national security concept of "overall national security concept", and China's new national security system is taking shape.

\section{Acknowledgements}

We acknowledge the Central South University (grant No. 2015zzts002) for financial support.

\section{References}

[1] Sining, Xu. (2011), Meisu de guojiaanquantizhibijiao, p7, Beijing, China:Beijing Party History press.

[2] Samuel P Huntington. (2000) The soldier and the state: The theory and Politics of Civil-Military Relation, Massachusetts, Cambridge The Belknap Press of Harvard University Press, $15^{\text {th }}$ printing.

[3] History of the National Security Council, 1947-1977 http://www. whitehouse.gov/nsc/history.html. 
[4] Melvyn A. LefEler, "A Preponderance of Power: National Security State, The Truman Administration and the ColdWar", Standford University Press. 1992. p. 175.

[5] Project on National Security Reform, Forging a New Shield, (Arlington:PNSR, 2008), P7.

[6] Pee, R. Int Polit (2018) 55: 693. https://doi.org/10.1057/s41311-017-0094-0.

[7] Ke, Niu. (2010), Meiguo guojiaanquan de chuangsheng, adapted from shixueyuekan.

[8] Stanton L. (2017) A New Frontier in US National Security Policymaking: State and Local Governments. In: Jacob E. (eds) Rethinking Security in the Twenty-First Century. Palgrave Macmillan, New York.

[9] Junjie, Wang. (2010), Zhanzhengfa (War law), P123, Kunming, Yunnan: Yunan University press.

[10] McConnon E. (2019) US Development Policy in the Ongoing War on Terror. In: Risk and the Security-Development Nexus. Rethinking International Development series. Palgrave Macmillan, Cham.
[11] Chongde, Xu. (2003), History of China's Constitution, P326. Fujian: Fuzhou People's press.

[12] Hui, Liu et Xiaochun, Zhao. (2014), Challenges and Confrontations: the national security situation in 2013, p13-17, Beijing, China: Shehuikexuewenxian press.

[13] Liping, Xia. (2013), zhongguo guojiaanquan yu diyuan zhengzhi, p1, Beijing, China: Social science press.

[14] Xiaodong, Wang. (2009), Research on national security leadership system, p73, Beijing, China: Shishi Presss.

[15] Jiangguang, Tang. Geti fanzui weixian zhongguo shehui, adapted from China's news week.

[16] Gaofeng, Jin. (2012), Dangqian Zhongguo Geren Jiduanbaoli Fanzui Yanjiu, adapted from Renming Gongan press. Yang, Zhang. Gonganbu bushu xiaqiu shehuizhian, People's Daily.

[17] Huilin, Hu. (2013), Introduction of National Cultural Security, p15, Shanghai, China: Shanghai people's press.

[18] Charles O. Jones. (2007), The American Presidency: A Very Short Introduction, P27, London, UK: Oxford University Press. 